\title{
Biblical Elements and the >Other in the Chronicon regum Legionensium
}

\author{
Patrick S. Marschner*
}

This article claims to bring to mind an almost forgotten text from the twelfth century Iberian Peninsula, the Chronicon regum Legionensium, and to show the relevance of the investigation of its biblical and transcultural elements. Next to the famous Historia Silense or the Chronica Adefonsi imperatoris, this text seems quiet marginal. However, a new approach to this small chronicle may offer new insights. Its author, the famous Bishop Pelayo of Oviedo, occasionally depicted the cultural and religious `Other in the Iberian Peninsula - the Muslim foreign rulers. In doing so, he partly added biblical allusions to these depictions. No research into the biblical elements and the perception and depiction of the Muslims in this chronicle has been done so far. Hence, the decidedly biblical investigation of this work will offer new possibilities for interpreting a text which is believed to be already well known. A new facet of the Chronicon regum Legionensium will be revealed.

Keywords: Historical writing; transculturality; Iberian Peninsula; Bible exegesis; typology; Christian-Muslim relations; ethnic terminology; ethnic identification; Bishop Pelayo of Oviedo; King Bermudo II of León, King Alfonse VI of León

\section{Introduction}

Whereas the production of Christian-Iberian historiographical texts between the fall of the Visigothic kingdom and the early eleventh century is quite manageable, numerous chronicles and gesta emerged in the north of the Peninsula during the twelfth century. The most famous from this later period may be the so-called Historia Silense ${ }^{1}$ and the Chronica Adefonsi imperatoris. ${ }^{2}$ Although both of them are worth investigating concerning the biblical elements they offer in correlation with the depiction of the cultural and religious ১Other८, in the following pages I would like to draw attention to a distinctly smaller, but not necessarily less

* Correspondence details: Patrick Marschner, M.A., Institut für Mittelalterforschung, Österreichische Akademie der Wissenschaften, Hollandstraße 11-13, 1020 Wien, Austria; Email: Patrick.Marschner@oeaw.ac.at.

1 Historia Silense, ed. Pérez de Urbel and González Ruiz-Zorilla, 113-209; among the huge number of studies on this chronicle, one could highlight the 2012 volume of the online journal e-Spania, ed. Martin, Historia legionensis (llamada silensis); Wreglesworth, Sallust, Solomon, 97-129; Barton, Islam and the West, 153-174. An overview on the studies on this chronicle is provided by Henriet, Historia Silense, 370-374.

2 Chronica Adefonsi imperatoris, ed. Maya Sánchez, 147-248; Barton and Fletcher, The world of el Cid, 148-161 offers a good overview; biblical elements in this chronicle were investigated by Pérez González, Influencias clasicas y biblicas, 349-355; an overview on other studies on this text can be found in Barton, Chronica Adefonsi Imperatoris, 611-615. 
influential, historiographical work, the Chronicon regum Legionensium. ${ }^{3}$ Compared to other contemporary chronicles, it has hardly been considered in research to date. ${ }^{4}$ However, investigation of this chronicle expands our knowledge about Christian-Iberian historical writing in the twelfth century. Even though it is a very small text, the biblical elements and the ethnonyms and denominations it contains have to be taken into account if we want to explore modes of identification, perception and depiction in transcultural Iberian societies. It might be just a small piece of the puzzle, but it offers insights into the intellectual structures and imagination of twelfth-century Christian-Iberian chroniclers.

In particular, its author, Bishop Pelayo of Oviedo, who influenced many of the later twelfth-century chronicles in the northern Iberian Peninsula, reveals his ideas on kinship, salvation history and the foreign rulers on the peninsula in this chronicle. Although Pelayo's bad reputation as rel fabulador occasionally dominates the discourse, he remains a very influential cleric in terms of both church politics and the Christian-Iberian historiographical tradition. ${ }^{5}$ No doubt, this also correlates with his role as a compiler and collector of historiographical works that resulted in the famous Corpus Pelagianum. Nevertheless, as yet, no one has investigated the biblical elements of Pelayo's chronicle.

\section{The chronicle}

The Chronicon regum Legionensium was most likely written between 1121 and $1132 .{ }^{6}$ The oldest surviving manuscript is part of the famous Corpus Pelagianum dated from the late twelfth century (Fig. 1). ${ }^{7}$ In each of the manuscripts from the Corpus Pelagianum, the Chronicon regum Legionensium follows the Chronicle of Sampiro ${ }^{8}$ and, thus, seems to be a continuation and partly an addition of this older chronicle. Consequently, it belongs, at least for the compiler, to the grand narrative of Iberian history from the Visigoths to the Umayyad invasion to the contemporary circumstances of twelfth-century Hispania. Since biblical subjects and universal-historical texts like the Chronicle of Albeld $a^{9}$ also appear in these manu-

3 Chronicon regum Legionensium, ed. Sánchez Alsonso; Concerning the influence of the Chronicon regum Legionensium on other texts from the 12th century, see Sánchez Alonso, Crónica del Obispo, 41-49; Barton and Fletcher, The world of el Cid, 73; Henriet, Chronica Naierensis, 779.

4 Huete Fudio, La historiografía Latina medieval, 31-32.

5 Casariego, Crónicas de los Reinos, 159-161; Linehan, History and the Historians, 78-79; Barton and Fletcher, The world of el Cid, 69-71; Alonso Álvarez, El obispo, 331-350; Alonso Álvarez, La obra histórica.

6 Barton and Fletcher, The world of el Cid, 73; a more precise, yet uncertain dating is offered by Sánchez Alonso, Crónica del Obispo, 9-10; Sánchez Alonso, Historia de la historiografía, 116; Pérez de Urbel, Pelayo de Oviedo, 393; Huete Fudio, La historiografía Latina medieval, 31.

7 Matr. BN 1513, fol. 64r-69v; another two versions of this chronicle are contained in BN 1358, fol. 49r-55r and BN 2805, fol. 65v-73r; Barton and Fletcher, The world of el Cid, 71; Alonso Álvarez, La obra histórica, 4; comprehensive manuscript studies were made by Sánchez Alonso, Crónica del Obispo, 17-33, and also by Pérez de Urbel, Sampiro, 165-196; Fernández Conde, El Libro de los Testamentos, 50-67; Casariego, Crónicas de los Reinos, 170-171; furthermore, Jerez, Arte compilatoria pelagiana, 66-87, especially 74-76 and 80, concerning the Chronicon regum Legionensium and the variations between those three manuscripts. See also Fernández Conde, Estudios, 155. On Pelayo generally, his bishopric and his role as collector and author of historiographical texts, see Fletcher, Episcopate, 72-74.

8 Chronicle of Sampiro, ed. Pérez de Urbel, 275-346.

9 Chronica Albeldensis, ed. Gil [Fernández], 435-484. 
scripts, the integration of the Chronicon regum Legionensium in this text corpus also means inclusion in salvation history. ${ }^{10}$ Considering the identical phrasings, the eleventh-century Chronicle of Sampiro presumably had a strong influence on Bishop Pelayo of Oviedo and the writing of his chronicle. ${ }^{11}$ Also, the Chronicle of Alfonse III ${ }^{12}$ and the Historia Silense affected the constitution of the Chronicon regum Legionensium, ${ }^{13}$ whereas Pelayo's work itself coined later historiographical texts such as the Chronica Adefonsi imperatoris or the Chronica Najerensis. ${ }^{14}$ Parts of the Chronicon regum Legionensium reappear also in the Chronica Najerensis. ${ }^{15}$

In his chronicle, Bishop Pelayo describes the history of the kingdom of León from the late tenth to the early twelfth century alongside its rulers, beginning with Bermudo II and ending with the death of Alfonse VI. ${ }^{16}$ Due to the comparatively small scope of the chronicle, it is not surprising that there are only a few biblical elements and references to the cultural and religious >Other . Yet, in the broader complex of twelfth-century Christian-Iberian historical writing, it helps explain some unclear phenomena such as the use of the ethnonym smoabitir or smoabitaric for denominating the foreign rulers in al-Andalus - a form of identification that cannot be found in the Iberian Peninsula before the twelfth century. Hence, the length of Pelayo's chronicle and the small number of biblical and transcultural references in it should not mislead us in estimating the value of this text.

10 Jerez, Arte compilatoria pelagiana, 68, 70; Alonso Álvarez, Ploraverunt lapides, 128.

11 Sánchez Alonso, Crónica del obispo, 44; Pérez de Urbel, Pelayo de Oviedo, 397; Barton and Fletcher, The world of el Cid, 71.

14 Sánchez Alonso, Crónica del obispo, 41-49; Barton and Fletcher, The world of el Cid, 73; Henriet, Chronica Naierensis, 779.

15 Henriet, Mille formis Daemon, 171, n. 47.

16 Sánchez Alonso, Historia de la historiografía, 116-117. 


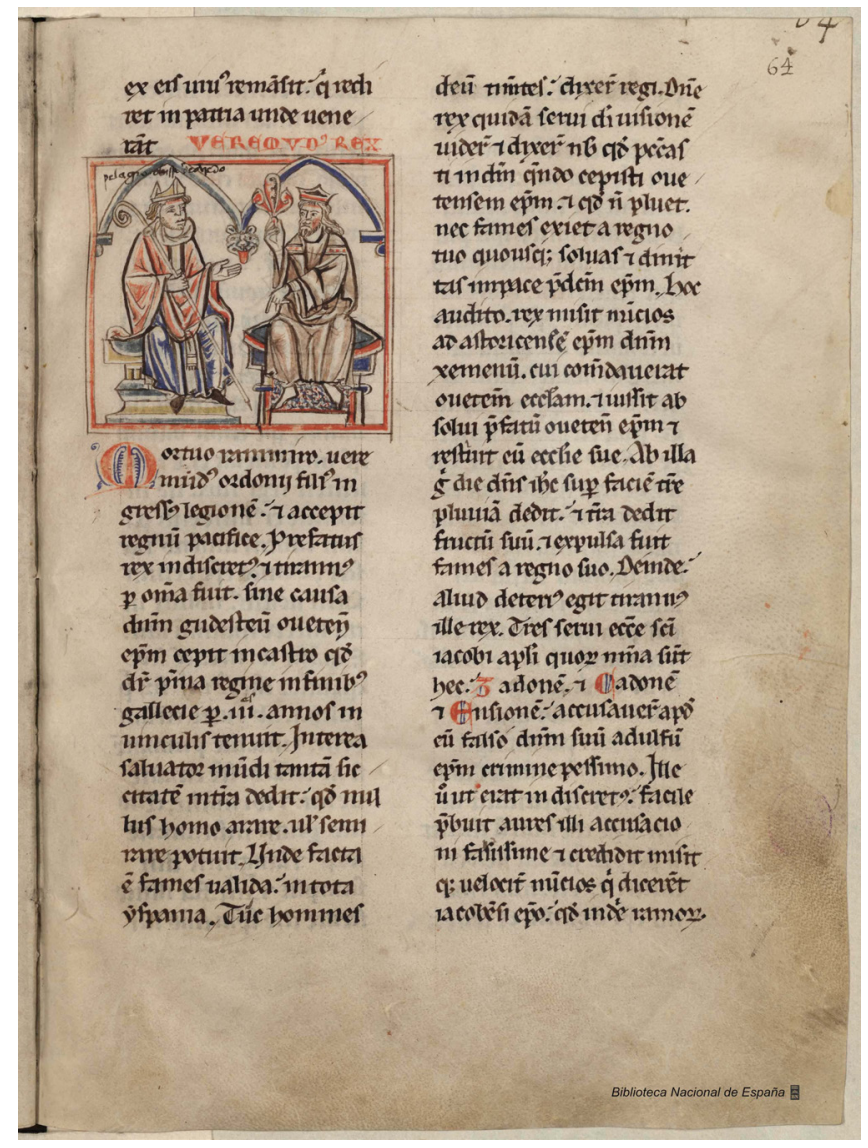

Fig. 1: The beginning of the Chronicon regum Legionensium in one manuscript of the famous Corpus Pelagianum. It shows bishop Pelayo sitting on the right of a king (perhaps Alfonse VI). 12th or 13th century. Matr. BN 1513, fol. 64r.

\section{State of current research}

The latest research on twelfth-century Christian-Iberian historiography mostly addresses the Chronicon regum Legionenium only sporadically. ${ }^{17}$ Even in the large volume by David Thomas and Alex Mallett on Christian-Muslim relations it does not appear, presumably precisely because the transcultural encounters play only a minor role in the chronicle. ${ }^{18}$ The bibliographic overview of Huete Fudio offers only a small number of works on this text, the latest of which date from the 1980 os. $^{19}$ One of them is the introduction to the Spanish translation by Casariego. ${ }^{20}$ The latest general investigation of Pelayo's chronicle is the introduction to its English translation in Barton and Fletcher's book on twelfth-century texts on the >Reconquistar from the year 2000. ${ }^{21}$ Older works such as Francisco Javier Fernández Conde's monograph on

17 Fernández Conde, Espacio y tiempo, 143-144; Alonso Álvarez, El Corpus Pelagianum, 532.

18 Thomas and Mallett (eds.), Christian-Muslim Relations, 69-786.

19 Huete Fudio, La historiografía latina medieval, 31-32.

20 Casariego, Crónicas de los Reinos, 159-171.

21 Barton and Fletcher, The world of el Cid, 65-74. 
the Liber Testamentorum, which also contains passages on bishop Pelayo as shistoriador ${ }^{22}$, or the encyclopaedic description of the text by Sánchez Alonso are also quite minimalistic regarding this chronicle. ${ }^{23}$ Sánchez Alonso was also the latest editor of the Chronicon regum Legionensium back in 1924. This edition also contains an investigation of the author, the manuscripts, historical impact and language of the chronicle. ${ }^{24}$

Apparently, to date there has generally been no strong research interest in the Chronicon regum Legionensium. Accordingly, no one has yet investigated its biblical elements. Furthermore, none of the abovementioned studies thematised any biblical elements, nor did any of the editions or translations mark them. Thus, we do not know as much as we could about this text. An investigation of this chronicle focusing on the biblical elements will close this gap in our knowledge. In the following investigation, the biblical elements as well as the ethnonyms for depicting the cultural and religious `Other will be examined in the same order as they appear in the Chronicon regum Legionensium.

\section{Biblical elements and the cultural and religious >Other}

The first passage of the Chronicon regum Legionensium referring to the Bible is the depiction of King Bermudo II, whom Pelayo describes as arbitrary and reckless. ${ }^{25}$ Pelayo's reason for this judgement of Bermudo II was the gratuitous incarceration of Bishop Gudesteo of Oviedo, which was ordered by the king. ${ }^{26}$ Yet, as we will see, there were many events that caused an especially negative depiction of Bermudo. The peak of them, for Pelayo, were the devastating casualties caused by the campaigns of Almanzor during the reign of Bermudo II. ${ }^{27}$ This subject will be addressed in detail below. As Pelayo explains, the incarceration of Gudesteo was a sin, which provoked an extreme drought in the kingdom as God's punishment for Bermudo: "Interea Salvator mundi tantam siccitatem in terra dedit, quod nullus homo arare vel seminare potuit, unde facta est fames valida in tota Ispania. $\aleph^{28}$ Subsequently, Pelayo continues, pious men went to the king, telling him that the drought was God's punishment for

22 Fernández Conde, El Libro de los Testamentos, 50-67.

23 Sánchez Alonso, Historia de la historiografía, 116-119.

24 Sánchez Alonso, Crónica del obispo, 9-56.

25 Chronicon regum Legionensium, ed. Sánchez Alonso, 57: „Mortuo Ranimiro, Veremudus Ordonii filius ingressus est Legionem, et accepit regnum pacifice. Prefatus rex indiscretus et tirannus per omnia fuit. « Transl. by Barton and Fletcher, The world of el Cid, 74: »On the death of Ramiro [II], Vermudo [II] the son of Ordoño [III] entered León and acquired the kingdom peacefully. That king was foolish and a tyrant in everything he did."

26 Chronicon regum Legionensium, ed. Sánchez Alonso, 57-58: „Sine causa dominum Gudesteum Ovetensem Episcopum cepit in castro quod dicitur Prima Regine in finibus Gallecie per tres annos in vinculis tenuit.« Transl. by Barton and Fletcher, The world of el Cid, 74: "Without any reason, he imprisoned Bishop Godesteo of Oviedo in the castle which is called Peña Reina on the borders of Galicia, and for three years he kept him in chains."

27 Barton and Fletcher, The world of el Cid, 72-73, 74, n. 2.

28 Chronicon regum Legionensium, ed. Sánchez Alonso, 58. Transl. by Barton and Fletcher, The world of el Cid, 74: "During that time the Saviour of the world gave such a drought on earth, that no man could either plough or sow, which caused great famine in all of Spain.« 
the king's decision to incarcerate Gudesteo. ${ }^{29}$ They convinced Bermudo and thereupon, he ordered the release of Gudesteo. Immediately, God led it rain. ${ }^{30}$

This episode's narrative structure followed the principle of sin, punishment, penance and mercy, which in this case coincided with a natural phenomenon. The same principle appears several times in the Old Testament. The term ssiccitas', which occurs in the text of the chronicle, also belongs to the terminology in the description of such a divine punishment in the book of Haggai: "respexistis ad amplius et ecce factum est minus et intulistis in domum et exsuflavi illud quam ob causam dicit Dominus exercituum quia domus mea deserta est et vos festinatis unusquisque in domum suam propter hoc super vos prohibiti sunt caeli ne darent rorem et terra prohibita est ne daret germen suum et vocavi siccitatem super terram et super montes et super triticum et super vinum et super oleum et quaecumque profert humus et super homines et super iumenta et super omnem laborem manuum ${ }^{31}{ }^{31}$ If a biblical-typological representation underlies this depiction and if this Bible quote was the response for Pelayo, the politics of Bermudo would represent the decline of the shouse of Godr. However, besides the book of Haggai there are further Old Testament episodes which report a drought as divine punishment for ungodly behaviour. Such examples can be found in Deuteronomy, ${ }^{32}$

29 Chronicon regum Legionensium, ed. Sánchez Alonso, 58: »Tunc homines Deum timentes dixerunt Regi: Domine Rex, quidam servi Dei visionem viderunt, et dixerunt nobis quod peccasti in Deum, quando cepisti Ovetensem Episcopum, et quod non pluet nec fames exiet a regno tuo, quousque solvas et dimittas in pace predictum Episcopum. " Transl. by Barton and Fletcher, The world of el Cid, 74: "Then some God-fearing men said to the king: >Lord King, some of God's servants have seen a vision, and have told us that you sinned before God when you imprisoned the bishop of Oviedo, and that it will not rain nor will famine leave your kingdom until you release the bishop and send him away in peacer.»

30 Chronicon regum Legionensium, ed. Sánchez Alonso, 58: „Ab illa igitur die Dominus Iesus super faciem terre pluviam dedit, et terra dedit fructum suum et expulsa fuit fames a regno suo. "Transl. by Barton and Fletcher, The world of el Cid, 75: "From that day, therefore, Lord Jesus gave rain over the face of the earth, the earth gave forth its fruit, and famine was expelled from his kingdom."

31 Agg 1, 9-11. Transl. (every translation of a Bible quote in this article is taken from the King James Bible): "You have looked for more, and behold it became less, and you brought it home, and I blowed it away: why, saith the Lord of hosts? because my house is desolate, and you make haste every man to his own house. Therefore the heavens over you were stayed from giving dew, and the earth was hindered from yielding her fruits: And I called for a drought upon the land, and upon the mountains, and upon the corn, and upon the wine, and upon the oil, and upon all that the ground bringeth forth, and upon men, and upon beasts, and upon all the labour of the hands."

32 Dt 28, 22: "percutiat te Dominus egestate febri et frigore ardore et aestu et aere corrupto ac robigine et persequatur donec pereas." Transl.: »The Lord shall smite thee with a consumption, and with a fever, and with an inflammation, and with an extreme burning, and with the sword, and with blasting, and with mildew; and they shall pursue thee until thou perish.« 
the third book of Kings, ${ }^{33}$ the Psalms, ${ }^{34}$ Jeremiah ${ }^{35}$ and in Zephaniah. ${ }^{36}$ All of these examples could equally be Pelayo's references. All of them explain a drought as the consequence of acting sinfully. Thus, the conflict between King Bermudo and the bishops is depicted through the structure of Old Testament morals.

Fernández Conde suggests the story of David and Uriah the Hittite from the second book of Samuel, particularly the threat formula of Nathan against David after Uriah's death, as background of this episode. ${ }^{37}$ In this case, the chronicle would refer to the story of King David, ambushing Uriah, and Bermudo would be depicted as second David - specifically stressing his negative characteristics - whereas Gudesteo would appear as second Uriah and, therefore, as victim of the betrayer. Yet, the passages of the second book of Samuel, mentioned by Fernández Conde, do not contain consistent vocabulary. ${ }^{38}$ Hence, this background is possible in terms of comparable tropes but it is without linguistic evidence. On the other hand, if we just have a look one verse further in the threat formula, at least one consistent term appears - peccatum, the $\sin .^{39}$ Nevertheless, this term appears so often in the Bible, there is no certainty that it refers explicitly to this passage. Furthermore, in the second book of Samuel David speaks of sin, whereas in the Chronicon regum Legionensium the "God-fearing men", not the king, use this term. Accordingly, the role allocation of such a connection would not work.

$333 \operatorname{Rg} 8$, 35: "si clausum fuerit caelum et non pluerit propter peccata eorum et orantes in loco isto paenitentiam egerint nomini tuo et a peccatis suis conversi fuerint propter adflictionem suam." Transl.: "When heaven is shut up, and there is no rain, because they have sinned against thee; if they pray toward this place, and confess thy name, and turn from their sin, when thou afflictest them."

34 Ps 67, 7: "Deus habitare facit solitarios in domo educit vinctos in fortitudine increduli autem habitaverunt in siccitatibus." Transl.: »God setteth the solitary in families: he bringeth out those which are bound with chains: but the rebellious dwell in a dry land.«

35 Ier 14, 1-10: "quod factum est verbum Domini ad Hieremiam de sermonibus siccitatis luxit Iudaea et portae eius corruerunt et obscuratae sunt in terra et clamor Hierusalem ascendit maiores miserunt minores suos ad aquam venerunt ad hauriendum non invenerunt aquam reportaverunt vasa sua vacua confusi sunt et adflicti et operuerunt capita sua propter terrae vastitatem quia non venit pluvia in terra confusi sunt agricolae operuerunt capita sua [...] haec dicit Dominus populo huic qui dilexit movere pedes suos et non quievit et Domino non placuit nunc recordabitur iniquitatum eorum et visitabit peccata eorum. "Transl.: »The word of the Lord that came to Jeremiah concerning the dearth. Judah mourneth, and the gates thereof languish; they are black unto the ground; and the cry of Jerusalem is gone up. And their nobles have sent their little ones to the waters: they came to the pits, and found no water; they returned with their vessels empty; they were ashamed and confounded, and covered their heads [...] Thus saith the Lord unto this people, Thus have they loved to wander, they have not refrained their feet, therefore the Lord doth not accept them; he will now remember their iniquity, and visit their sins."

36 So 2, 13: "et extendet manum suam super aquilonem et perdet Assur et ponet speciosam in solitudinem et in invium et quasi desertum. "Transl.: »And he will stretch out his hand against the north, and destroy Assyria; and will make Nineveh a desolation, and dry like a wilderness."

37 Fernández Conde, El Libro de los Testamentos, 65.

$382 \mathrm{Sm} \mathrm{12,1-12.}$

392 Sm 12, 13: »et dixit David ad Nathan peccavi Domino dixitque Nathan ad David Dominus quoque transtulit peccatum tuum non morieris. « Transl.: »And David said unto Nathan, I have sinned against the Lord. And Nathan said unto David, The Lord also hath put away thy sin; thou shalt not die.» 
Bermudo II had a dispute with another bishop. The chronicle reports that three servants of the church of St. Jacob in Santiago de Compostela accused their bishop Adolfo ${ }^{40}$ of $>$ the worst crimer and Bermudo believed them. ${ }^{41}$ Subsequently, the king ordered that bulls be mustered and chose the wildest among them. Then he sent messengers to Bishop Adolfo, who summoned the bishop to come to the king. At the stipulated place, Bermudo intended to release the bull on Adolfo. ${ }^{42}$ When the messengers commanded Adolfo to go to the king, the bishop replied that he would first consult the >King of kings a and go to Bermudo afterwards: »Pontifex vero, constituto die, Ovetum venit. Cui milites Regi dixerunt ut prius veniret ad Regem quam Ecclesiam intraret. Ipse vero, fultus in Domino, dixit: Ego ibo ad Regem Regum prius et Salvatorem nostrum, et postea veniam ad tirannum Regem vestrum ${ }^{4}{ }^{43}$ So, Adolfo first wanted to go to Jesus, which means that he first wanted to read the mass in church. The terminology rrex regum r is taken from the Bible and can be matched to the first letter to Timothy ${ }^{44}$ or the book of Revelation. ${ }^{45}$ In contrast to the biblical terminology in the quotation above, this Bible allusion has no typological meaning. Rather, it seems to be mere religious terminology. In addition, a possible reference to the book of Daniel, especially the interpretation of the dream of Nebuchadnezzar, when Daniel calls the Babylonian king rex regem ${ }^{46}$, cannot be verified from the chronicle's narrative context.

The episode of Adolfo and the bull continues with the bishop going to the stipulated place to meet the king. ${ }^{47}$ There, Bermudo commanded the release of the bull. However, the animal peacefully laid his horns into the hands of Bishop Adolfo and did him no harm. After that, the bull ran back into the forest, where it came from and killed numerous mockers on his way.

40 Actually, no contemporary bishop of Santiago de Compostela was named Adolfo. Comp. Sánchez Alonso, Crónica del obispo, 45-46.

41 Chronicon regum Legionensium, ed. Sánchez Alonso, 58-59: „Deinde aliud deterius egit tirannus ille Rex: tres serui Ecclesie Sancti Iacobi Apostoli, quorum nomina sunt hec Zadonem et Cadonem et Ensionem, accusauerunt apud eum falso dominum suum Adulfum Episcopum crimine pessimo. Ille uero, ut erat indiscretus, facile prebuit aures illi accusationi falsissime, et credidit [...].« Transl. by Barton and Fletcher, The world of el Cid, 75: "Then that tyrant king did a worse thing. Three servants of the church of St James the Apostle, whose names were Zadón, Cadón and Ensión, falsely accused their lord Bishop Adaúlfo, of the very worst of crimes before him. And since Vermudo was foolish, he readily lent his ears to those very false accusations and believed them.«

42 Chronicon regum Legionensium, ed. Sánchez Alonso, 59-60.

43 Chronicon regum Legionensium, ed. Sánchez Alonso, 59. Transl. Barton and Fletcher, The world of el Cid, 75: "So the bishop came to Oviedo on the appointed day. The king's soldiers told him that he should go first to the king before he entered the church. But he, supported by God, said: 'First I shall go to the King of Kings and Our Saviour, and afterwards I shall come to your tyrant king.«

$441 \operatorname{Tim} 6$, 15: "quem suis temporibus ostendet beatus et solus potens rex regum et Dominus dominantium. «Transl.: "Which in his times he shall shew, who is the blessed and only Potentate, the King of kings, and Lord of lords."

45 Apc 17, 14: »hii cum agno pugnabunt et agnus vincet illos quoniam Dominus dominorum est et rex regum et qui cum illo sunt vocati et electi et fideles."Transl.: »These shall make war with the Lamb, and the Lamb shall overcome them: for he is Lord of lords, and King of kings: and they that are with him are called, and chosen, and faithful«; Apc 19, 16: "et habet in vestimento et in femore suo scriptum rex regum et Dominus dominantium. « Transl.: »And he hath on his vesture and on his thigh a name written, King of kings, and Lord of lords.«

46 Dn 2, 37: »tu rex regum es et Deus caeli regnum fortitudinem et imperium et gloriam dedit tibi.« Transl.: »Thou art a king of kings: and the God of heaven hath given thee a kingdom, and strength, and power, and glory.«

47 Chronicon regum Legionensium, ed. Sánchez Alonso, 59-60. 
Then Adolfo went to the church of Oviedo, threw the horns of the bull in front of the altar, excommunicated his three servants and cursed their descendants and King Bermudo. ${ }^{48}$ This narration partly seems to refer to a specific Old Testament episode. Adolfo opposed a false order as Gideon did in the book of Judges on God's command. Gideon was told to destroy the altar of Baal with a bull and afterwards sacrifice the animal. ${ }^{49}$ Both narrations contain a bull, which plays an essential role in overcoming false religious conditions. Likewise, there is one opposing figure in each episode. Yet Gideon is a salvation figure, whereas Adolfo, through his actions, appears as a prophet, who announced the misery coming over the kingdom and for which Bermudo was responsible.

The entire depiction of Bermudo II's policies against the bishops seems to be a prologue, leading in the narrative thread of the chronicle directly to the arrival of Almanzor and, thus, to the destruction of a large part of the kingdom of León. Before the coming of Almanzor, the result of Bermudo's sins, Pelayo inserts another episode, which does not refer to Bermudo himself but to his daughter Teresa and which also contains Bible allusions. In contrast to Bermudo, his daughter is depicted in a very positive manner. As we read in the chronicle, Teresa was given by her brother Alfonse $\mathrm{V}$ as wife to the spagan king of Toledo - who was the Arab governor of the city - to preserve peace with him. ${ }^{50}$ However, Teresa did not agree with these marriage politics. She told the governor of Toledo not to touch her, since he was

48 Chronicon regum Legionensium, ed. Sánchez Alonso, 60: „Tunc Rex taurum dimitti precepit. Ille autem velociter cucurrit, et cornua in manu Episcopi dimisit, et reversus multos derisores interfecit, postea silvas, unde venerat, petiit. Episcopus itaque ad Ecclesiam reversus, cornua que in manibus tenebat ante altare nostri Salvatoris proiecit et Chadonem et Ansionem et Zadonem excommunicavit, et oravit et dixit quod de semine eorum usque in finem mundi quidam essent leprosi, et alii ceci, et alii claudi, et alii manci propter crimen falsum quod imposuerant ei. Et maledixit Regi, et dixit quod in semine eius surrexiset palam, cunctis viventibus, hoc scelus." Transl. by Barton and Fletcher, The world of el Cid, 75: »Then the king ordered the bull to be set loose and it ran very swiftly and surrendered its horns into the hand of the bishop. Turning back, it killed many scoffers, and afterwards returned to the woods from where it had come. Then the bishop returned to the church, threw down the horns that he was holding in front of the altar of Our Saviour and excommunicated Cadón, Ensión and Zadón. And he prayed and said that of their seed right up until the end of the world some would be lepers and others blind, some lame and others crippled, because of the false crime they had laid upon him. And he cursed the king and said that this crime had openly arisen in his seed whilst all of them were living."

49 Idc 6, 25-28: "nocte illa dixit Dominus ad eum tolle taurum patris tui et alterum taurum annorum septem destruesque aram Baal quae est patris tui et nemus quod circa aram est succide et aedificabis altare Domino Deo tuo in summitate petrae huius super quam sacrificium ante posuisti tollesque taurum secundum et offeres holocaustum super lignorum struem quae de nemore succideris adsumptis igitur Gedeon decem viris de servis suis fecit sicut praeceperat Dominus timens autem domum patris sui et homines illius civitatis per diem facere noluit sed omnia nocte conplevit cumque surrexissent viri oppidi eius mane viderunt destructam aram Baal lucumque succisum et taurum alterum inpositum super altare quod tunc aedificatum erat. "Transl.: »And it came to pass the same night, that the Lord said unto him, Take thy father's young bullock, even the second bullock of seven years old, and throw down the altar of Baal that thy father hath, and cut down the grove that is by it: And build an altar unto the Lord thy God upon the top of this rock, in the ordered place, and take the second bullock, and offer a burnt sacrifice with the wood of the grove which thou shalt cut down. Then Gideon took ten men of his servants, and did as the Lord had said unto him: and so it was, because he feared his father's household, and the men of the city, that he could not do it by day, that he did it by night. And when the men of the city arose early in the morning, behold, the altar of Baal was cast down, and the grove was cut down that was by it, and the second bullock was offered upon the altar that was built."

50 Chronicon regum Legionensium, ed. Sánchez Alonso, 63: „Ipsam vero Tarasiam post mortem patris sui dedit frater eius Adefonsus in coniugo, ipsa nolente, cuidam pagano regi toletano pro pace.« Transl. by Barton and Fletcher, The world of el Cid, 77: "After the death of her father, Teresa was given away in marriage by her brother Alfonso to a certain pagan king of Toledo for the sake of peace, although she was herself unwilling." 
a pagan. Otherwise, `God's angel «ould kill him: »Ipsa autem, ut erat christiana, dixit pagano regi: Noli me tangere, quia paganus es; si vero me tetigeris Angelus Domini interfeciet te. ${ }^{51}$ Yet, the governor was unfazed by Teresa's words and mocked her and touched her anyway. Immediately, 'God's angel struck him down: "Tunc rex derisit eam, et concubit cum ea semel, et statim, sicut predixerat, percussus est ab Angelo Domini. ${ }^{52}$ Teresa was then released and returned to León. ${ }^{53}$ Teresa's threat against the governor contains a quotation from the New Testament. Furthermore, the story of Teresa and the governor structurally refers to three Old Testament episodes. The refusal of permission to touch her (noli me tangere) matches the words Jesus spoke to Mary Magdalene after his resurrection. ${ }^{54}$ The death by >God's angel ${ }^{55}$ (angelus Domini percussit), by contrast, corresponds with motifs from the fourth book of Kings ${ }^{56}$ and Isaiah. ${ }^{57}$ Placing Teresa in a typological correlation with Jesus due to the John quote is surely not appropriate, since there are no parallels in the storylines of the Chronicon regum Legionensium and the New Testament. By contrast, it seems likely that Pelayo wanted to depict Teresa as being under God's protection. Both of the Old Testament episodes that relate to the quotation of `God's angel refer to the victory against the Assyrian king Sennacherib. In both biblical books 'God's angel struck down his army of 150,000 men. Accordingly, the governor of Toledo could be the antitype $e^{58}$ of Sennacherib, whereas Teresa represents the whole of the new chosen people, the Iberian Christians. Furthermore, the immediate death by touching of a pagan or an unauthorized person shows parallels to

51 Chronicon regum Legionensium, ed. Sánchez Alonso, 63-64 Transl. by Barton and Fletcher, The world of el Cid, 77: »But as she was a Christian, she said to the pagan king: >Do not touch me, for you are a pagan. If you do touch me the Angel of the Lord will slay you.«

52 Chronicon regum Legionensium, ed. Sánchez Alonso, 64. Transl. by Barton and Fletcher, The world of el Cid, 77: "Then the king laughed at her and slept with her once, and just as she had predicted, he was immediately struck down by the Angel of the Lord."

53 Chronicon regum Legionensium, ed. Sánchez Alonso, 64.

54 Io 20, 17: »dicit ei Iesus noli me tangere nondum enim ascendi ad Patrem meum vade autem ad fratres meos et dic eis ascendo ad Patrem meum et Patrem vestrum et Deum meum et Deum vestrum. « Transl.: "Jesus saith unto her, touch me not; for I am not yet ascended to my Father: but go to my brethren, and say unto them, I ascend unto my Father, and your Father; and to my God, and your God.»

55 Most likely the Old Testament origin of this rangel of death is to be found in Ex 12, the famous episode of God killing every first born Egyptian to put pressure on the pharaoh. Later biblical mentions of this trope seem to relate to this episode.

$564 \operatorname{Rg}$ 19, 35: "factum est igitur in nocte illa venit angelus Domini et percussit castra Assyriorum centum octoginta quinque milia cumque diluculo surrexisset vidit omnia corpora mortuorum et recedens abiit." Transl.: "And it came to pass that night, that the angel of the Lord went out, and smote in the camp of the Assyrians an hundred fourscore and five thousand: and when they arose early in the morning, behold, they were all dead corpses."

57 Is 37, 36: »egressus est autem angelus Domini et percussit in castris Assyriorum centum octoginta quinque milia et surrexerunt mane et ecce omnes cadavera mortuorum." Transl.: »Then the angel of the Lord went forth, and smote in the camp of the Assyrians a hundred and fourscore and five thousand: and when they arose early in the morning, behold, they were all dead corpses."

58 >Antitype here means that the governor's death appears as fulfilment of the Old Testament prediction of the defeat of Sennacherib. They represent the typological idea of two phenomena having the same meaning in salvation history but appearing separated in time - one announcing, the other fulfilling. See Ohly, Halbbiblische und außerbiblische Typologie, 433 . 
the Arc of the Covenant. ${ }^{59}$ Hence, Teresa plays a major role in the narration thread of the chronicle, because as a Christian in the control of a pagan she is under special protection from God and her story is therefore an important element that contributes to the depiction of the cultural and religious >Other in the Iberian Peninsula. Yet, one has to mention that she does not appear in any other text of post-conquest Christian-Iberian historical writing until the twelfth century. ${ }^{60}$ Additionally, even if we can verify the biblical origin of Teresa's quotation, it is likely that it has been conveyed, or at least influenced, by a liturgical text, the Liber Ordinum. ${ }^{61}$

After Teresa's story, the chronicler reports on the campaigns of Almanzor, the shagarene kings, and his son Abd al-Malik against the kingdom of León. Pelayo again denotes Bermudo II as the cause for the invasion of the hostile troops. ${ }^{62}$ The attack by Almanzor is obviously caused by the sins of the Leonese king. The moral causality that is transferred in the course of history is an usual mode of depicting negative events in post-conquest Christian-Iberian historical writing. ${ }^{63}$ In the same way, the identification of the foreign rulers as descendants of the Biblical figure Hagar, the bondwoman of Abraham with whom he begat Ishmael ${ }^{64}$, is clearly an Iberian tradition. ${ }^{65}$ In that way, it was possible for Pelayo to explain the historical events in the kingdom he lived in and to identify the cultural and religious >Other', who were devastating this kingdom. The answers of who and why were found in the authoritative texts in the Bible.

$592 \mathrm{Sm}$ 6, 6-7: "postquam autem venerunt ad aream Nachon extendit manum Oza ad arcam Dei et tenuit eam quoniam calcitrabant boves iratusque est indignatione Dominus contra Ozam et percussit eum super temeritate qui mortuus est ibi iuxta arcam Dei.« Transl.: "And when they came to Nachon's threshing floor, Uzzah put forth his hand to the ark of God, and took hold of it; for the oxen shook it. And the anger of the Lord was kindled against Uzzah; and God smote him there for his error; and there he died by the ark of God."

60 During the twelfth century, this story reappears in the Chronica Najerensis. See Henriet, Mille formis Daemon, 171; Chronica Najerensis, ed. Estéves Sola, II, § 34, 141 and again § 40, 147-148.

61 Henriet, Mille formis Daemon, 171; Alonso Álvarez, The cruces gemmatae, 65; Liber ordinum episcopal de Santo Domingo de Silos, ed. Janini [Cuesta], III, § 22, 77: "Signum salutis pone domine in domibus istis ut non permittas introire angelum percutientem in domibus in quibus vos habitatis pono signum meum dicit dominus et protegam vos et non erit in vobis plaga.« Transl. by the author: "Lord, put the sign of welfare onto this house, so you may not let the angel of death pass through it; [as] the Lord said: put my sign on the house, in which you live and I will protect you and the plague will not get in«, which again is very similar to Ex 12, 13: »erit autem sanguis vobis in signum in aedibus in quibus eritis et videbo sanguinem ac transibo vos nec erit in vobis plaga disperdens quando percussero terram Aegypti.« Transl.: "And the blood shall be to you for a token upon the houses where ye are: and when I see the blood, I will pass over you, and the plague shall not be upon you to destroy you, when I smite the land of Egypt.« See above, n. 55.

62 Chronicon regum Legionensium, ed. Sánchez Alonso, 65: "Igitur propter peccata memorati principis Veremudi et populi, Rex Agarenus cui nomen erat Almanzor, una cum filio suo Adamelch, et cum christianis comitibus exiliatis, disposuerunt venire, et destruere, et depopulari Legionense Regnum.« Transl. by Barton and Fletcher, The world of el Cid, 78: "On account of the sins of Prince Vermudo and the people, the king of the Hagarenes, whose name was Amanzor, together with his son Adamelch and some exiled Christian counts, prepared to come and destroy and lay waste the kingdom of León."

63 Tischler and Marschner, The Bible in Historical Perception, 209-210; Marschner, The Depiction of the Saracen Foreign Rule.

64 Gn 16, 1-16.

65 Tischler and Marschner, The Bible in Historical Perception, 209-210. Earlier, on the Old Testament iconography in León, which also refers to the story of Abraham and his sons, see Williams, Generationes Abrahae, 7-11; among the almost uncountable literature on ethnonyms given to Arabs or north-African people, one could highlight Tolan, A wild man, 513-530. 
The chronicle continues with a description of the campaigns of Almanzor, ${ }^{66}$ which ended in the narration of God showing mercy for the Christians and striking all the >Hagarenes down. ${ }^{67}$ Hence, in a historical course of events, the Christian people went through the moral phases of sin, punishment, penance and mercy. Bermudo suffered an individual punishment when he died from gout, which was, as Pelayo repeatedly commented, caused by his sins. ${ }^{68}$

The next Bible allusions in the Chronicon regum Legionensium appear almost at the end of the text, during the description of King Alfonse VI's reign. Shortly before the death of the king, a strange phenomenon occurred in the church of St. Isidore in León: water ran out of the stones of the church's altar, not out of the joints in between the stones, at the sixth hour. ${ }^{69}$ After the water had kept flowing for several days, the clerics of St. Isidore in León drank the water during a mass and kept the rest of it. ${ }^{70}$ Bishop Pelayo, author of the chronicle and self-declared witness of this event, offers his own interpretation of the flowing water: it is an omen of the grief and misery that will befall Hispania after King Alfonse's death. This made the stones of the altar of St Isidore cry. ${ }^{71}$

66 Chronicon regum Legionensium, ed. Sánchez Alonso, 65-68.

67 Chronicon regum Legionensium, ed. Sánchez Alonso, 68: „Sed Rex celestis, solita pietate, memorans misericordie sue, ulcionem fecit de inimicis suis. Morte etenim quidam subitanea et gladio ipsa gens Agarenorum cepit assidue interire, et ad nichilum cotidie devenire. « Transl. by Barton and Fletcher, The world of el Cid, 79: »But the heavenly king, with His customary piety, remembering His mercy, wrought vengeance on His enemies: that very people of the Hagarenes began to fall away ceaselessly by sudden death and by the sword, and day by day to come closer to annihilation.«

68 Chronicon regum Legionensium, ed. Sánchez Alonso, 68: „Prefatum etiam Veremudum Regem pro tantis sceleribus que gessit, percussit eum Dominus podagrica infirmitate, ita quod deinceps nullum vehiculum ascendere potuit, sed in humeris humilium hominum de loco ad locum gestabatur dum vixit; et in Berizo vitam finivit [...]. « Transl. by Barton and Fletcher, The world of el Cid, 79: "The Lord struck down King Vermudo with gout because of all the sins that he had committed, so that he was unable from that time forward to climb into any carriage, but whilst he lived was carried from place to place on the shoulders of humble men. He ended his life in the Bierzo [...].«

69 Chronicon regum Legionensium, ed. Sánchez Alonso, 84-85: »Cum iam tempus immineret mortis eius [...] fecit Deus in Legionensem urbem in ecclesia Sancti Isidori Episcopi magnum prodigium. In Nativitate Sancti Iohannis Babtiste, hora sexta, in lapides qui sunt ante altare Sancti Isidori, ubi tenet sacerdos pedes quando Missam celebrat, non per iunturas lapidum, sed per medias petras cepit manare aqua, videntibus cunctis civibus [...].« Transl. by Barton and Fletcher, The world of el Cid, 86: "When the time of his death was very near [...] God worked a great wonder in the church of Bishop Saint Isidore in the city of León. On the feast day of the nativity of Saint John the Baptist, at the sixth hour of the day, water began to flow through the stones which are in front of the altar of Saint Isidore, where the priest stands when he celebrates Mass; not through the cracks between the stones, but through the middle of the stones. This was seen by all the citizens [...].« Alonso Álvarez, Ploraverunt lapides, 127-141 investigates this episode of Alfonse's death in the Chronicon regum Legionensium concerning its historiographic and hagiographic traditions and impacts, yet does not mention any biblical correlation.

70 Chronicon regum Legionensium, ed. Sánchez Alonso, 85.

71 Chronicon regum Legionensium, ed. Sánchez Alonso, 85-86: »Hoc signum nichil aliut protendit nisi luctus et tribulaciones que post mortem predicti Regis evenerunt Hispanie; ideo ploraverunt lapides et manaverunt aquam.« Transl. by Barton and Fletcher, The world of el Cid, 87: "This sign presaged none other than the sorrows and tribulations that befell Spain after the death of the aforesaid king; that is why the stones wept and the water flowed forth. « On the interpretation of this passage see Fernández Conde, El Libro de los Testamentos, 59, 61-62. 
The trope of water flowing out of stones is known from the book of Exodus, when Moses hit a rock with his staff on behalf of God, so water ran out of the rock and the thirsting people of Israel could drink. In that way, their morale was strengthened..$^{72}$ Subsequently, Joshua was able to defeat Amalech as long as Aaron and Hur sustained the Arms of Moses, who was thus strengthened by the support of his people. ${ }^{73}$ Since Pelayo interpreted the phenomenon in the church of St. Isidore as an announcement of bad things to come, this story rather relates to Psalms. Psalm 77 contains a history of the people of Israel and thereby refers to the aforementioned episode from the book of Exodus, yet with a negative addition: even though God gave his people water in times of misery, they did not trust him and sinned against him. In this way, they attracted God's wrath. ${ }^{74}$ If Pelayo claimed to depict this episode in a typological way, it remains unclear what the misery was that should have befallen the kingdom after Alfonse's death, yet the basic structure of this story correlates with the Old Testament: after water flows out of stones, bad things will happen.

The description of the water from the altar presumably contains another Bible allusion. It was said that the water started flowing in the sixth hour (hora sexta). This time designation could be a parallel to the New Testament. In the Gospel of John, Jesus encounters a Samaritan woman at the well of Jacob at the sixth hour. ${ }^{75}$ During their encounter, Jesus reveals to her that he is the Messiah. ${ }^{76}$ The combination of the tropes of time and water seems to increase the possibility of a New Testament reference. Finally, in the case of a New Testament correlation, the component of salvation history would enter the depiction. Bearing all this in mind, water flowing out of rocks at the sixth hour seems to express forthcoming misery but also salvation thereafter. The principle of hope, which is a permanent feature of the Bible, is also an important part of Pelayo's Chronicon regum Legionensium.

72 Ex 17, 6: "en ego stabo coram te ibi super petram Horeb percutiesque petram et exibit ex ea aqua ut bibat populus fecit Moses ita coram senibus Israhel.« Transl.: "Behold, I will stand before thee there upon the rock in Horeb; and thou shalt smite the rock, and there shall come water out of it, that the people may drink. And Moses did so in the sight of the elders of Israel."

73 Ex 17, 8-13.

74 Ps 77, 16-22: »et eduxit rivos de petra et elicuit quasi flumina aquas et addiderunt ultra peccare ei ut provo-carent Excelsum in invio et temptaverunt Deum in cordibus suis petentes cibum animae suae et loquentes contra Deum dicebant numquid poterit Deus ponere mensam in solitudine ecce percussit petram et fluxerunt aquae et torrentes inundaverunt numquid et panem poterit dare aut praeparare carnem populo suo ideo audivit Dominus et non distulit et ignis accensus est in Iacob et furor ascendit in Israhel quia non crediderunt Deo nec habuerunt fiduciam in salutari eius. "Transl.: "He brought streams also out of the rock, and caused waters to run down like rivers. And they sinned yet more against him by provoking the most High in the wilderness. And they tempted God in their heart by asking meat for their lust. Yea, they spake against God; they said, Can God furnish a table in the wilderness? Behold, he smote the rock, that the waters gushed out, and the streams overflowed; can he give bread also? can he provide flesh for his people? Therefore the Lord heard this, and was wroth: so a fire was kindled against Jacob, and anger also came up against Israel; Because they believed not in God, and trusted not in his salvation."

75 Io 4, 6: "erat autem ibi fons Iacob Iesus ergo fatigatus ex itinere sedebat sic super fontem hora erat quasi sexta." Transl.: "Now Jacob's well was there. Jesus therefore, being wearied with his journey, sat thus on the well: and it was about the sixth hour.»

76 Io $4,1-26$. 
Furthermore, the extradition of Jesus by Pilatus to the Jews in the Gospel of John was in the sixth hour. ${ }^{77}$ Finally, in the remaining Gospels the death of Jesus is connected with a darkness that fell in the sixth hour. ${ }^{78}$ All of these biblical passages refer to the death of Jesus. The story about the flowing water in the Chronicon regum Legionensium belongs to the narration of King Alfonse VI's death. Hence, the sixth hour correlates in each case with the death of a king, even though two different types of kings. Definitely, Alfonse is no antitype of Christ in this text - this would be presumptuous. Yet, he is depicted as very close to Christ, as an exceedingly pious king. As such, his death is announced similarly to the death of the 'King of kings،. This trope of the sixth hour, therefore, has no typological meaning. Rather its function is to depict Alfonse VI in the most positive manner, even though it is related to a negative event, i.e. the forthcoming misery of his kingdom. Through this depiction, and also through other describing elements in the Chronicon regum Legionensium, Alfonse VI is undoubtedly depicted as a just ruler. At this point, Pelayo's chronicle differs fundamentally from the Historia Silense, a work from the early twelfth century, in which Alfonse is very likely portrayed as the opposite. ${ }^{79}$

After listing the descendants of Alfonse VI, Pelayo describes the death of the king. While moaning about the king's death, Pelayo reveals what the misery will be that shall befall the kingdom - the Saracens.$^{80}$ Their coming was announced by the water in the church of St. Isidore and preluded by the dying king. 'Shepherd, why have you deserted your sheep? a asked

77 Io 19, 14: »erat autem parasceve paschae hora quasi sexta et dicit Iudaeis ecce rex vester. « Transl.: »And it was the preparation of the passover, and about the sixth hour: and he saith unto the Jews, Behold your King."

78 Mt 27, 45: "a sexta autem hora tenebrae factae sunt super universam terram usque ad horam nonam.« Transl.: "Now from the sixth hour there was darkness over all the land unto the ninth hour«; Mc 15, 33: »et facta hora sexta tenebrae factae sunt per totam terram usque in horam nonam«. Transl.: »And when the sixth hour was come, there was darkness over the whole land until the ninth hour«; Lc 23, 44: »erat autem fere hora sexta et tenebrae factae sunt in universa terra usque in nonam horam. "Transl.: "And it was about the sixth hour, and there was a darkness over all the earth until the ninth hour."

79 Wreglesworth, Sallust, Solomon, 104. On the depiction of Alfonse VI see Fernández Conde, El Libro de los Testamentos, 39, 47.

80 Chronicon regum Legionensium, ed. Sánchez Alonso, 87: "Ipse vero gloriosus Rex vixit LXXVIIII annis, XL tribus et VI mensibus ex eis in regno. Obiit Kalendas Julii in Tholeto Era MCXLVII. Quinta feria illucescente, flentibus cunctis civibus et dicentibus: Cur pastor oves deseris? Nam commendatum tibi gregem et regnum inuadent enim eum Sarraceni et maliuoli homines. "Transl. by Barton and Fletcher, The world of el Cid, 88: "This glorious king lived for 79 years, and reigned for 43 years and six months. He died in Toledo on the first of July in the Era 1147 [= AD 1109], early on Thursday morning, wherepon all the citizens wept and shouted: >O shepherd why have you deserted your sheep? Now the Saracens and evil men will fall upon the flock which has been entrusted to you and your kingdom.« 
Pelayo ${ }^{81}$ The trope of the sflock without a shepherd also appears in the book of Ezekiel. ${ }^{82}$ The book of Ezekiel tells the story of the chosen people losing and regaining their status before God following the causality of sin, punishment, penance and mercy. In the passage in Ezekiel, thematising the sflock without a shepherd of punishment and penance. Salvation is about to come. Equally, the Christian people in the Chronicon regum Legionensium have to face suffering before experiencing salvation.

In addition to the Ezekiel reference, the trope of the sflock without a shepherd also hints at the Gospel of John. There the confused flock is endangered by a wolf. ${ }^{83}$ If Pelayo's choice of terminology refers to the New Testament, it is possible he tried to depict the Saracens as threatening wolves. In that way, the invaders would have been the fulfilment of a New Testament prediction. It is uncertain which biblical passage might be the basis for Pelayo's depiction. In the case of Ezekiel, the Saracens would be understood as an echo of Gog, God's scourge in this Old Testament book. In the case of the Gospel of John, the invaders were the fulfilment of a threatening creature and the Christian would be warned not to turn away from God and his law. In any case, the terminology is biblical and, as such, offers the key to interpreting distinctly the perception and depiction of the cultural and religious `Other from Pelayo's point of view.

\section{Ethnonyms and denominations of groups}

The aforementioned denomination of Toledo's governor as spagan king ${ }^{84}$ certainly is a religious classification of his beliefs, yet this terminology never refers to a group in the text. It appears only in the singular and only refers to the person of the governor. There is no other appearance of the term paganus. We cannot be certain whether it identifies an entire group or explicitly classifies this one governor. In any case, it is a judging term, criticising the foreign religion.

81 Chronicon regum Legionensium, ed. Sánchez Alonso, 87: „Cur pastor oves deseris? « Transl. by Barton and Fletcher, The world of el Cid, 88: »O shepherd why have you deserted your sheep? «Alonso Álvarez, Ploraverunt lapides, 136137 also thematizes this quote, yet again does not correlate it to the Bible.

82 Ez 34, 5: "et dispersae sunt oves meae eo quod non esset pastor et factae sunt in devorationem omnium bestiarum agri et dispersae sunt.«Transl.: "And they were scattered, because there is no shepherd: and they became meat to all the beasts of the field, when they were scattered«; Ez 34, 8: »vivo ego dicit Dominus Deus quia pro eo quod facti sunt greges mei in rapinam et oves meae in devorationem omnium bestiarum agri eo quod non esset pastor neque enim quaesierunt pastores gregem meum sed pascebant pastores semet ipsos et greges meos non pascebant." Transl.: "As I live, saith the Lord God, surely because my flock became a prey, and my flock became meat to every beast of the field, because there was no shepherd, neither did my shepherds search for my flock, but the shepherds fed themselves, and fed not my flock. " As Alonso Álvarez, Ploraverunt lapides, 137 realized, there are very similar expressions in the twelfth-century Historia Compostellana, ed. Falque Rey, 40o. Yet, the editor of this gesta also marked them as taken from Ezekiel 13,5. Hence, even if we know about a textual tradition, we need to discuss the biblical origins of some tropes, paraphrases or quotations.

83 Io 10,12: "Mercennarius et qui non est pastor cuius non sunt oves propriae videt lupum venientem et dimittit oves et fugit et lupus rapit et dispergit oves." Transl.: "But he that is a hireling, and not the shepherd, whose own the sheep are not, seeth the wolf coming, and leaveth the sheep, and fleeth: and the wolf catcheth them, and scattereth the sheep."

84 Chronicon regum Legionensium, ed. Sánchez Alonso, 63-64. 
Much clearer is the identification of the cultural and religious >Other as >Hagarenes manzor is named their king and they appeared as a punishment for the sins of Bermudo II. ${ }^{85}$ This ethnonym is used four times in this chronicle and each time refers to Muslims attacking the kingdom of León. ${ }^{86}$

Almanzor is also the key figure in identifying the `Hagarenes with the 'Saracens`. As already shown, he is designated as shagarene king«. Additionally, the form sking of the Hagarenes appears, too. ${ }^{87}$ In the description of one of his attacks during Bermudo's reign, he is also called `king of the Saracens ${ }^{88}{ }^{8}$ Accordingly, >Hagarenes and `Saracens are represented as identical by Pelayo of Oviedo. The term 'Saracens appears five times in the chronicle. ${ }^{89}$

Furthermore, the chronicler offers a contemporary definition of the Almoravides, who, as he said, came from Africa to Hispania due to the numerous victories of King Alfonse VI..$^{90}$ Pelayo knows the origin of the Almoravides in Africa, which older chronicles like the Historia Silense also cite as the origins of the >Moors<. It is surprising that the clear distinction between >Moors and `Saracens that can be proven in Christian-Iberian chronicles from the seventh to the eleventh centuries disappears in the twelfth century Christian-Iberian historical writing. In the Historia Silense these two ethnonyms have the same meaning. ${ }^{91}$ The reason may be the appearance of the Almoravides, who were Africans like the >Moors and took over the reign in al-Andalus, which had been previously ruled by the sSaracensı. Nevertheless, the ethnonym >Almoravides` appears only once in the Chronicon regum Legionensium.

85 Chronicon regum Legionensium, ed. Sánchez Alonso, 65: "Igitur propter peccata memorati principis Ueremudi et populi, Rex Agarenus cui nomen erat Almanzor [...] disposuerunt uenire, et destruere, et depopulari Legionense Regnum. «Transl. by Barton and Fletcher, The world of el Cid, 78: „On account of the sins of Prince Vermudo and the people, the king of the Hagarenes, whose name was Amanzor [...] prepared to come and destroy and lay waste the kingdom of León."

86 Chronicon regum Legionensium, ed. Sánchez Alonso, 65, 68, 71, 73-74.

87 Chronicon regum Legionensium, ed. Sánchez Alonso, 71: »Tunc prefatus Rex Adefonsus venit Legioni [...] et repopulavit Legionensem urbem, que fuerat depopulata a predicto Rege Agarenorum Almazor [sic] [...].« Transl. by Barton and Fletcher, The world of el Cid, 80: "Then King Alfonso came to León [...] [and] resetteled the city of León which had been laid waste by King Almanzor of the Hagarenes [...].«

88 Chronicon regum Legionensium, ed. Sánchez Alonso, 66: "Predictus itaque Rex Sarracenorum, sicut disposuerat, venit cum exercitu magno et destruit Legionem, et Astoricam, et Coiancam, et circumadiacentes regiones devastavit.« Transl. by Barton and Fletcher, The world of el Cid, 78: »Then the aforesaid king of the Saracens came with a big army as he planned and destroyed León, Astorga and Valencia de Don Juan, and he devastated the surrounding area."

89 Chronicon regum Legionensium, ed. Sánchez Alonso, 66, 73, 80, 81, 87.

90 Chronicon regum Legionensium, ed. Sánchez Alonso, 82: »Post hec etiam prosperitatibus ad tantam elationem pervenit, ut extraneas gentes que Almorabites vocantur ex Africa in Spania per regem Abenabet misit, cum quibus prelia multa fecit et multa contumelia dum vixit accepit ab eis." Transl. by Barton and Fletcher, The world of el Cid, 85: "After this, he reached such a pitch of elation because of such good fortune that at the instigation of King Abenabet some foreigners called Almoravids were summoned from Africa to Spain, with whom he fought many battles, and whilst he lived he suffered many attacks by them."

91 Barton and Fletcher, The world of el Cid, 85, n. 73. 


\section{Conclusion}

The analysis of the Chronicon regum Legionensium showed its relevance for the investigation of Biblical elements in historical writing in transcultural contexts. The biblical elements in it convey a moral principle that is transferred to the course of history. In this way, the self-identification as new chosen people is demonstrated, for instance through the episode of Teresa and the governor of Toledo, as well as through the drought that befell the kingdom of León. Godliness as a device to defeat one's enemies is another important motif in the text. Furthermore, the depiction of the cultural and religious `Other biblical-genealogical origins is essential. Through these moral, exegetical and typological expressions, the Chronicon regum Legionensium fits perfectly in the tradition of post-conquest Christian-Iberian historical writing. ${ }^{92}$

Concerning the ethnonyms and denominations in it, this chronicle offers much less information than other Christian-Iberian historiographical works, which is ultimately also caused by its scope. It synonymously uses the ethnic terms 'Hagarenes` and 'Saracens`, which, again, fits in historiographical traditions in the Iberian Peninsula.

\section{Acknowledgements}

I would like to thank Matthias M. Tischler (Universitat Autònoma de Barcelona) for sharing his thoughts on this topic with me. He commented on this work during the process of formation. Furthermore, I want to thank John Wreglesworth (Leeds), who talked to me in person about 12th-century Hispania and bestowed important literature about this subject on me. I am also very thankful for the redaction work on this article undertaken by Ingrid Hartl (Institute for Medieval Research, Austrian Academy of Sciences). She was very open-minded to the idea that I could publish this article in this issue. Finally, I thank Walter Pohl (Institute for Medieval Research, Austrian Academy of Sciences and University of Vienna), who encouraged me to write for Medieval Worlds.

92 Tischler and Marschner, The Bible in Historical Perception, 207-212. 


\section{References}

Texts

Chronica Adefonsi imperatoris, ed. Antonio Maya Sánchez, in: Emma Falque [Rey], Juan Gil [Fernández] and Antonio Maya Sánchez (eds.), Chronica Hispana saeculi XII 1, Corpus Christianorum Continuatio Medievalis 71 (Turnhout, 1990) 147-248.

Chronica Adephonsi III, ed. Juan Gil [Fernández], in: Chronica Hispana saeculi VIII et IX. Cura et studio, Corpus Christianorum Continuatio Medievalis 65 (Turnhout, 2018) 383433.

Chronica Albeldensis, ed. Juan Gil [Fernández], in: Chronica Hispana saeculi VIII et IX. Cura et studio, Corpus Christianorum Continuatio Medievalis 65 (Turnhout, 2018) 435-848.

Chronica Najerensis, ed. Juan Antonio Estéves Sola, Chronica Naierensis. Chronica Hispana saeculi XII 2, Corpus Christianorum Continuatio Medievalis 71 A (Turnhout, 1995) 1-181.

Chronicle of Sampiro, ed. Fausto Justo Pérez de Urbel, Sampiro. Su cronica y la monarquia Leonesa en el siglo X, Escuela de estudios medievales, Estudios 26 (Madrid, 1952) 275346.

Chronicon regum Legionensium, ed. Benito Sánchez Alonso, Crónica del obispo Don Pelayo, Textos Latinos de la Edad Media Española, Volúmenes publicados, Sección Primera: Crónicas 3 (Madrid, 1924) 57-88.

Historia Compostellana, ed. Emma Falque Rey, Historia Compostellana, Corpus Christianorum Continuatio Medievalis 70 (Turnhout, 1987) 1-530.

Historia Silense, ed. Fausto Justo Pérez de Urbel and Atilano González Ruiz-Zorrilla, Historia Silense. Edicion, critica e introduccion, Escuela de Estudios Medievales, Textos 30 (Madrid, 1959) 113-209.

Liber ordinum episcopal de Santo Domingo de Silos, ed. José Janini [Cuesta], Liber ordinum episcopal (Cod. Silos, Arch. Monástico, 4), Studia Silensia 15 (Santo Domingo de Silos, 1991) 59-329.

\section{Studies}

Alonso Álvarez, Raquel, El obispo Pelayo de Oviedo (1101-1153). Historiador y promotor de códices iluminados, Semata. Ciencias Sociais e Humanidades 22 (2010) 331-350.

Alonso Álvarez, Raquel, Ploraverunt lapides et manaverunt aquam. El planto por el rey según las crónicas de los reinos occidentales hispánicos, in: Damien Boquet and Piroska Nagy (eds.), Politiques des émotions au Moyen Âge, Micrologus' library 34 (Firenze, 2010) 115148.

Alonso Álvarez, Raquel, El Corpus Pelagianum y el Liber Testamentorum ecclesiae Ouetensis. Las «reliquias del pasado» de la cathedral de Oviedo y su uso propagandístico en la obra del Obispo Pelayo de Oviedo (1101-1153), in: Marie-Françoise and Robert Braid (eds.), Texte et Conteste. Littérature et Histoire de l'Europe médiévale, Actes du Colloque, Université Paris-Est Marne-la-Vallée, 23-24 octobre 2009 (Paris, 2011) 519-548.

Alonso Álvarez, Raquel, La obra histórica del obispo Pelayo de Oviedo (1089-1153) y su relación con la Historia legionensis (llamada silensis), in: Georges Martin (ed.), Historia legionensis (llamada silensis). Écriture de l'histoire, Historiographie léonaise, castillane et navarraise de XIIe siècle 3, L'Historia (dite) Silensis, e-Spania. Revue interdisciplinaire d'études hispaniques médiévales et modernes (14 December 2012). Retrieved on 9th October 2018 from: journals.openedition.org/e-spania/21586. 
Alonso Álvarez, Raquel, The cruces gemmatae of Oviedo between the eleventh and twelfth centuries, Journal of Medieval Iberian Studies 9/1 (2017) 52-71.

Barton, Simon and Fletcher, Richard, The world of el Cid. Chronicles of the Spanish Reconquest, Manchester Medieval Sources (Manchester/New York, 2000).

Barton, Simon, Islam and the West. A View from Twelfth-Century León, in: Simon Barton and Peter Linehan (eds.), Cross, Crescent and Conversion. Studies on Medieval Spain and Christendom in Memory of Richard Fletcher, The Medieval Mediterranean, Peoples Economies and Cultures, 400-1500, 73 (Leiden/Boston, 2008) 153-174.

Barton, Simon, Chronica Adefonsi Imperatoris, in: David Thomas and Alex Mallett (eds.), Christian-Muslim Relations. A Bibliographical History 3 (1050-1200), History of Christian-Muslim Relations 15 (Leiden/Boston, 2011) 611-615.

Casariego [Fernández-Noriega], Jesús Evarista, Crónicas de los Reinos de Asturias y León, Biblioteca universitaria Everest (León, 1985).

Fernández Conde, Francisco Javier, El Libro de los Testamentos de la catedral de Oviedo, Publicaciones del Instituto Español de Estudios Eclesiásticos, Monografías 17 (Roma, 1971).

Fernández Conde, Francisco Javier, Espacio y tiempo en la construcción ideológica de Pelayo de Oviedo, in: Patrick Henriet (ed.), A la recherche de légitimités chrétiennes. Représentations de l'espace et du temps dans l'Espagne médiévale (IXe-XIIIe siècle), Annexes des Cahiers de linguistique et de civilisation hispaniques médiévales 15 (Lyon, 2003) 129-148.

Fernández Conde, Francisco Javier, Estudios sobre la monarquía asturiana, Piedras Angulares (Gijón, 2015).

Fletcher, Richard, The Episcopate in the Kingdom of León in the Twelfth Century, Oxford historical monographs (Oxford, 1978).

Henriet, Patrick, Mille formis Daemon. Usages et fonctions de la croix dans l'Hispania des IXe-XIe siècles, in: Thomas Deswarte and Philippe Sénac (eds.), Guerre, pouvoirs et idéologies dans l'Espagne chrétienne aux alentours de l'an mil. Actes du Colloque international organisé par le Centre d'Etudes Supérieures de Civilisation Médiévale, Poitiers-Angoulême (26, 27 et 28 septembre 2002), Culture et société médiévales 4 (Turnhout, 2005) 163-181.

Henriet, Patrick, Chronica Naierensis, in: David Thomas and Alex Mallett (eds.), Christian-Muslim Relations. A Bibliographical History 3 (1050-1200), History of Christian-Muslim Relations 15 (Leiden/Boston, 2011) 778-782.

Henriet, Patrick, Historia Silense, in: David Thomas and Alex Mallett (eds.), Christian-Muslim Relations. A Bibliographical History 3 (1050-1200), History of Christian-Muslim Relations 15 (Leiden/Boston, 2011) 370-374.

Huete Fudio, Mario, La Historiografía latina medieval en la Península Ibérica (siglos VIIIXII), Fuentes y Bibliografía (Madrid, 1997).

Jerez, Enrique, Arte compilatoria pelagiana: la formación del Liber cronicorum, in: Amaia Arizaleta (ed.), Poétique et chronique. L'écriture des textes historiographiques au Moyen Âge (péninsule Ibérique et France), Méridiennes. Série Études médiévales ibériques (Toulouse, 2008) 47-87.

Linehan, Peter, History and the Historians of Medieval Spain (Oxford, 1993).

Ohly, Friedrich, Halbbiblische und außerbiblische Typologie, in: Simboli e simbologia nel'Alto Medioevo, 3-9 aprile 19752 (Spoleto, 1976) 429-472.

Marschner, Patrick Sebastian, The Depiction of the Saracen Foreign Rule in the "Prophetic Chronicle« Through Biblical Knowledge, Journal of Transcultural Medieval Studies 5/2 (2018) forthcoming. 
Martin, Georges (ed.), Historia legionensis (llamada silensis). Écriture de l'histoire, Historiographie léonaise, castillane et navarraise de XIIe siècle 3, L'Historia (dite) Silensis, e-Spania. Revue interdisciplinaire d'études hispaniques médiévales et modernes (14 December 2012). Retrieved on 9th October 2018 from: journals.openedition.org/espania/21568.

Pérez de Urbel, Fausto Justo, Pelayo de Oviedo y Sampiro de Astorga, Hispania 11 (1951) 387-412.

Pérez de Urbel, Fausto Justo, Sampiro. Su crónica y la monarquía Leonesa en el siglo X, Escuela de Estudios Medievales, Estudios 26 (Madrid, 1952).

Pérez González, Maurilio, Influencias clasicas y biblicas en la Chronica Adefonsi Imperatoris, in: Maurilio Pérez González (ed.), Actas I congreso nacional de latin medieval (León, 1-4 de diciembre de 1993) (León, 1995) 349-355.

Sánchez Alonso, Benito, Crónica del obispo Don Pelayo. Textos Latinos de la Edad Media Española, Volúmenes publicados, Sección Primera: Crónicas 3 (Madrid, 1924).

Sánchez Alonso, Benito, Historia de la historiografía española 1, Hasta la publicación de la Crónica de Ocampo (...-1543) (Madrid, 1947).

Thomas, David and Mallett, Alex (eds.), Christian-Muslim Relations. A Bibliographical History 3 (1050-1200), History of Christian-Muslim Relations 15 (Leiden/Boston, 2011).

Tischler, Matthias Martin and Marschner, Patrick, The Bible in Historical Perception and Writing of the Transcultural Iberian Societies, Eighth to Twelfth Centuries, Medieval Worlds 5 (2017) 195-220.

Tolan, John Victor, >A wild man, whose hand will be against all: Saracens and Ishmaelites in Latin Ethnographical Traditions, from Jerome to Bede, in: Walter Pohl, Clemens Gantner and Richard Payne (eds.), Visions of Community in the Post-Roman World. The West, Byzantium and the Islamic World, 300-110o (Farnham, 2012) 513-530.

Williams, John, Generationes Abrahae: Reconquest Iconography in Leon, Gesta 16/2 (1977) 3-14.

Wreglesworth, John, Sallust, Solomon and the Historia Silense, in: David Hook (ed.), From Orosius to the Historia Silense. Four Essays on the Late Antique and Early Medieval Historiography of the Iberian Peninsula, Bristol Medieval Studies 2 (Bristol, 2005) 97-129.

\section{List of illustrations}

Figure 1: Mart. BN 1513, fol. 64r. Link: bdh-rd.bne.es/viewer.vm?id=0ooooo599o\&

page $=133$ (retrieved on 24th September 2018). 